Volume 8 Issue 3 March 2020

\title{
SPDC and Sustainable Development in the Niger Delta Region of Nigeria: An Appraisal of the GMoU Model and Implementation Process in Three selected Clusters of Land East Hub
}

\author{
Kenneth Nweke, Ph.D \\ Department of Political Science \\ Ignatius Ajuru University of Education \\ Rumuolumeni, Port Harcourt, Rivers State, Nigeria \\ kenneth.nweke@iaue.edu.ng
}

$\mathrm{DOI}<10.26821 / \mathrm{IJSRC} .8 .3 .2020 .8311>$

\begin{abstract}
This study essentially focussed on appraising SPDC's Global Memorandum of Understanding (GMoU) model and Implementation Process in three selected clusters of Land East Hub. The study has argued that SPDC's operations in the Niger Delta region have engaged several development models in host communities in a bid to deliver on her Corporate Social Responsibilities. The GMoU model, as part of sustainable development efforts of Shell Petroleum Development Company of Nigeria Limited (SPDC), was a replacement of the previous Sustainable Community Development approach with a view to providing funds on annual basis for a period of five years to enable host communities drive their own development process. Although SPDC was not the first IOC in Nigeria to adopt and implement this new global community development model, yet its GMoU model and implementation process have remained one of the most successful in the history of sustainable community development processes in the country. How the entire GMoU model and implementation process as well as the Implementing and Facilitating NGOs have fared in managing the process within the Land East Hub, no doubt, constitute the main problem in this study. Therefore, the study (a mixed method/design) is both qualitative and quantitative, hence adopted evaluation/survey research design to interrogate the GMoU model and the implementation process in the three selected clusters of the Land East Hub since inception in 2006.Four hypotheses tested positive except one, an indication that the GMoU model and implementation process have substantially complied with the principles and objectives of the Operating Principles and Procedure Guidelines (OPPG). The study concludes that in spite of the achievements of the GMoU model in host communities, the need to overhaul the implementation process has become imperative to sustain the community-driven development process. The study, therefore, recommends a return to early years of GMoU implementation process at inception where all the GMoU focal points religiously lived up to the dictates of the OPPG with a view to closing the widening gaps and addressing the age-long development needs of the oil host communities on sustainable basis.
\end{abstract}

Keywords: GMoU Model, OPPG, Sustainable Development, SPDC, Implementation Process and Land East Hub Clusters

\section{Section One: Introduction}

\subsection{Background to the Study}

It will be interesting to note that the enthusiasm with which the current GMoU model received accolades at inception appears to be gradually dying down as the modus operandi and intended objectives appear too far from being realised.

Kenneth Nweke, Vol 8 Issue 3, pp 38-63 March 2020 
Volume 8 Issue 3 March 2020

There is no doubt that there is growing concern among host communities and critical stakeholders regarding the GMoU model initiated by SPDC in 2006 vis-à-vis the Community Assistance projects being operated ab initio. This is largely due to perceived fundamental problems between programme conception and implementation process especially as it concerns fundamental principles upon which the programme was established. It is clearly stated in the OPPG that the delivery of the GMoU will be guided by the fundamental principles of sustainable development, good governance, inclusiveness, transparency and accountability. Consequently, there appears to be some gaps between the current GMOU model and the implementation process. This concern has affected the psyche of many host communities as well as other critical stakeholders. There is no gainsaying that the way and manner host communities on land greeted what they called "chairing news" on hearing that Belema Oil was bidding for the land operations of SPDC, was a clear indication of one of those concerns. Operating in that kind of environment, where there are already seeds of discord and disenchantment does not portend good image for SHELL in spite of the enormity of both human and material resources deployed to sustaining the GMoU process for over ten years running.

There is no gainsaying the fact that SPDC as a company has demonstrated strong commitments towards sustainable development in the host communities. The company's mission statement as captured in SPDC (n.d) clearly stated thus:

SPDC is committed to sustainable development and supports development and progress within our communities. The overall goal of our social investment programmes is to leverage the resources and empower local communities to take the lead in their own development. Over the years, our social investment programmes have undergone transformations geared at achieving sustainable development. In 2006, we began testing a new approach to improve the way we engage with communities and the effectiveness of projects, as well as to empower communities to make their own development decisions. We introduced new agreements called Global Memorandum of Understanding (GMoUs) with communities grouped into clusters. Through GMOUs, the SPDC- operated joint venture provides secure multi-year funding for development projects and access to expertise. The communities decide how to spend the money. By the end of 2009, the joint venture had funded a total of 250 projects (including pre- MoU legacy projects) using the GMoU model. (p.1)

SPDC, having reviewed the previous sustainable community development approach, decided to come up with a more sustainable approach in providing funds on annual basis for a period of five years to enable host communities drive their own development process through the Global Memorandum of Understanding (GMoU). Although many have argued that SPDC was not the first IOC in Nigeria to adopt and implement this new global community development model, yet its GMoU model and implementation process have remained one of the most successful in the history of sustainable community development process in the country. In spite of its intentions in addressing the agelong development needs of the oil host communities, the GMoU model and implementation process need to be interrogated with a view to determining the extent to which gaps exist there in so that the original intentions of its founding fathers would not only be achieved but sustained amid certain expressions of discontentment by some host communities in the oil-rich region.

\subsection{Statement of the Problem}

SPDC's operations in the Niger Delta region has engaged several development models in host communities in a bid to deliver on her Corporate Social Responsibilities. As a responsible corporate citizen, certain factors guide her in the choice and implementation of any type of development model suitable for her host communities. Study Team Report (2006) did not mince words when it clearly stated that:

Over the years, the approach that SPDC adopts to tackle community interface issues has been a reflection of prevailing social and business context and corporate community engagement paradigms. A major turning point was the 1998 change from community assistance to community development approach. The key feature of that transformation was the use of participatory approaches in the delivery of services, projects and programmes. However, after a major review in 2002, the company adopted the SCD model. (p.6) 
The Sustainable Community Development (SCD) model mainly focussed on "Social Development and referred to all activities, effort and expenditure related to helping local communities to improve and maintain their capabilities to generate and sustain their own socio-economic progress, quality of life and health" (SCD Presentation to NAPIMS, 2003, cited in Study Team Report, 2006, p. 6). Years after it was in place, the need to replace the SCD model became inevitable in view of a mix bag of stagnation and appreciable movement towards the achievement of CD-SCD transition objectives. Before the advent of SCD model, Community Development approach was in operation but failed to achieve the desired objectives of SPDC. The reputational issues generated by SCD model, in the wisdom of the company, far outweigh the gains in areas it made some progress, hence the urgent need to rejig the model which gave birth to the current Global Memorandum of Understanding (GMoU) in 2006 with enormous resources committed to achieving great feat in sustainable development in host communities. The GMoU model was a product of genuine efforts by the company to improve the lot of the host communities.

It is in the light of the above, that this research becomes imperative to undertake with a view to identifying and closing possible gaps between the GMoU model and the implementation process. In other words, this research will focus on appraising the GMoU model and implementation strategies taking into cognisance the strengths and weaknesses of the current process for improvement in line with its principles and objectives. It is pertinent to state that the GMoU process, introduced in 2006, is "an agreement between SPDC and a group (or cluster) of several communities" (OPPG, 2017, p.1\&https//www.shell.com.ng/sustainability/communities/gmou.html). The GMoU is a new way of working with communities. Clusters are based on local government or clan/historical affinity lines as advised by the relevant state government. The GMoUbrings communities together with representatives of state and local governments, SPDC and non-profit organisations, such as development NGOs, in a decision-making committee called the Cluster Development Board (CDB). The document provides that "communities decide the development they want while SPDC on behalf of its joint venture partners, provides secure funding for five years, ensuring that the communities have stable and reliable finances as they undertake the implementation of their community development plans" (OPPG, 2017, p. 2). The OPPG (2017, p. 2) clearly states that "the GMoUs or agreements represent an important shift in approach, placing emphasis on more transparent and accountable processes, regular communication with the grassroots, sustainability and conflict prevention". Having been in operation over the last ten years, this study sets out to interrogate how the GMoU process has fared in living up to its objectives of achieving sustainable development of the host communities within the principles of transparency, accountability, inclusiveness and conflict mediation in the management of the GMoU process in three selected clusters of Land East Hub of Shell Petroleum Development Company of Nigeria Limited. Despite the huge resources running into millions of dollars deployed to realising sustainable development in the host communities, through the GMoU process over a decade, much still leaves to be desired in achieving these intended objectives especially when viewed against the backdrop of the type and quality of projects conceived and executed since inception in 2006.It is on record that the "social investment funds disbursed for community-driven projects under the Global Memorandum of Understanding (GMoU) structure by SPDC JV since inception in 2006 amounts to N44.36 billion (\$239 million)" (Shell Nigeria Briefing Notes, 2019, p. 8). There is therefore the need to march this huge funding of the plethora of the GMoU projects with the actual needs of the people which aims at achieving sustainable development within the principles of transparency, accountability, inclusiveness and conflict management set out in the OPPG.

There is no doubt that the roles of the Mentoring and Facilitating NGOs in managing the GMOU process become also very pertinent to assess in view of the enormity of resources expended in hiring their services and the sensitivity in dealing with host communities as they remain the major drivers of the process on the front ends. How the entire GMoU model and implementation process as well as the Implementing and Facilitating NGOs have fared in delivering on their mandates for the overall benefits of SPDC JV partners and the host communities within the Land East Hub, no doubt, constitute the major problem in this study. 
Volume 8 Issue 3 March 2020

\subsection{Objectives of the Study}

The main purpose of this study is to determine the extent to which gaps exist between the GMoU model and the implementation process with a view to closing them for the overall benefit of both SPDC and host communities. The study specifically aims to achieve the following five objectives:

(i) Determine how the GMoU implementation process has fared in achieving sustainable development in three selected clusters of Land East Hub since inception.

(ii) Ascertain the applicability and functionality of the principles of transparency and accountability in the implementation of the GMoU process in three selected clusters of Land East Hub over the years.

(iii) Ascertain the extent to which the CDBs/CTs have implemented the principle of inclusiveness in the GMoU process in three selected clusters of Land East Hub over time.

(iv) Determine the roles of the CDBs/CTs in grievance handling in the GMoU implementation process in three selected clusters of Land East Hub since inception.

(v) Examine the roles of successive Mentoring and Facilitating NGOs in the GMoU process in three selected clusters of Land East Hub over the years.

\subsection{Research Questions}

To this end, this study in setting out to achieve the above objectives, will achieve thosewith the following five research questions:

(i) To what extent has the GMoU implementation process been able to achieve sustainable development in three selected clusters of Land East Hub since inception?

(ii) To what extent has the GMoU process been transparently and accountably managed by the CDBs/CTs in line with the extant principles in three selected clusters of Land East Hub over the years?

(iii) To what extent has the principle of inclusiveness been implemented in the GMoU process by the $\mathrm{CDBs} / \mathrm{CT}$ s in three selected clusters of Land East Hub over time?

(iv) To what extent have the CDBs/CTs activated the grievance handling procedures as enshrined in the GMoU model in resolving the myriad of conflicts arising from the implementation process in three selected clusters of Land East Hub since inception?

(v) To what extent have successive Mentoring and Facilitating NGOs helped to add values to the GMoU process in three selected clusters of Land East Hub over the years?

\subsection{Hypotheses}

Five null hypotheses are to be tested in this study. They include the following:

$\mathrm{HO}_{1}$ : The CDBs/CTs do not significantly differ in their perception that the GMoU process has achieved sustainable development in three selected clusters of Land East Hub.

$$
\mu_{1}=\mu_{2}=\mu_{3} \quad \text { or } \quad \mu_{1}-\mu_{2}-\mu_{3}=0
$$

$\mathrm{HO}_{2}$ : There is no significant difference in the perception of the CDBs/CTs that the GMoU process has been transparently and accountably managed in line with extant principles of the model in three selected clusters of Land East Hub.

$$
\mu_{1}=\mu_{2}=\mu_{3} \quad \text { or } \quad \mu_{1}-\mu_{2}-\mu_{3}=0
$$

$\mathrm{HO}_{3}$ :The $\mathrm{CDBs} / \mathrm{CTs}$ do not differ in their perception that the principle of inclusiveness has been substantially implemented in the GMoU process in line with extant principles of the model in three selected clusters of Land East Hub.

$$
\mu_{1}=\mu_{2}=\mu_{3} \quad \text { or } \quad \mu_{1}-\mu_{2}-\mu_{3}=0
$$


Volume 8 Issue 3 March 2020

$\mathrm{HO}_{4}$ : The CDBs/CTs do not differ in their perception that the grievance handling procedures as enshrined in the GMoU model have been substantially activated in resolving the myriad of conflicts arising from the implementation process in three selected clusters of Land East Hub.

$$
\mu_{1}=\mu_{2}=\mu_{3} \quad \text { or } \quad \mu_{1}-\mu_{2}-\mu_{3}=0
$$

$\mathrm{HO}_{5}$ : The CDBs/CTs do not significantly differ in their perception that successive Mentoring and Facilitating NGOs have substantially added values to the GMoU process in three selected clusters of Land East Hub.

$$
\mu_{1}=\mu_{2}=\mu_{3} \quad \text { or } \quad \mu_{1}-\mu_{2}-\mu_{3}=0
$$

\subsection{Significance of the Study}

The significance of any research is a measure of how much it has contributed in enhancing existing knowledge and literature in the subject of study. This study therefore is not an exception. The significance of our study has both theoretical and empirical underpinnings. On the theoretical significance, we shall within the limit of resources available to us, give a fairly sufficient illumination of SPDC and Sustainable Development in the host communities especially as it affects her GMoU process. Due to the emergence of sustainability considerations in contemporary global development approach, this study will assume a critical role as an intellectual basis of decisionmaking in the course of resource allocation and distribution by SPDC and her JV Partners in the Niger Delta region. In this regard, the study has so much to offer to both micro and macro-stakeholders of development enterprise in the Niger Delta with a view to finding a lasting solution to the long years of sustainable development crises in the region. This study will also build upon the knowledge, skills and values of SPDC and her JV Partners to strengthen their capacity to improve the socio-economic and environmental conditions of host communities especially when considered against the backdrop of the enormity of oil resources in the region with little or no substantial development. Similarly, the theoretical significance of this study is set against the background of the vital role of sustainable development in the host communities considering the fact that the resources accruing to Nigeria largely come from the region. On the empirical significance of this study, our findings in this study will help SPDC JV Partners to review the GMoU model and the implementation process with a view to ensuring that the laudable efforts they began over a decade ago would achieve the desired objectives especially at this period when some critical stakeholders have begun to accuse the company of failing to implement the GMoU she entered with the host communities. This study would help to create a better understanding of the problem and build the much-needed synergy with major stakeholders in the Niger Delta in which sustainable development issues have remained unresolved over the years despite the commitment of SPDC and other IOCs in addressing the long years of neglect of the region. There is no doubt that this study would underscore the need for the SPDC and her JV Partners to begin a dialogue process that will dovetail into their development actions complementing those of other relevant stakeholders instead of the current trend where the latter is complementing the former. This study would serve as a reference material for further research in this regard. The study is, therefore, intended to stimulate further debates and contribute to the on-going discourse on whether the GMoU process is working or not considering the enormity of millions of dollars expended by SPDC since inception in this regard amid accusations of non-implementation of the GMoU by some stakeholders. This will in no small measure help to create an enabling environment that would douse the heightened security situation and underdevelopment in the region with a view to resolving the protracted and seemingly insurmountable sustainable development crises which have ravaged the oil host communities.

\subsection{Scope of the Study}

The scope of this study includes an appraisal of SPDC's GMoU model and the implementation process relative to the sustainability or otherwise of her development efforts in addressing the very fundamental challenges confrontingthe host communities since 2006 when she began the implementation of the new development model - the GMoU. This implies that this is basically an evaluation/survey study to determine whether the GMoU model has contributed in substantial measures in the improvement of the quality of life of the host communities delineated in 
Volume 8 Issue 3 March 2020

clusters for the sole purpose of achieving sustainable development through enduring physical and social infrastructure (roads, electricity, pipe borne water) and economic empowerment programmes (employment, skills acquisition/training, scholarship, micro-credit and poverty alleviation/reduction schemes) while also not compromising effective environmental management for not just the inhabitants of today's host communities but the future generations as well.

Similarly, the scope of work extensively borders on identification of possible gaps between the GMoU model and implementation process in Etche 1, Ikwerre and Ukwa West Clusters of Land East Hub randomly selected with a view to closing them for the overall benefit of both the company and host communities. Initially we had planned to extend our study to three clusters across the three Hubs but funding and security issues in the Niger Delta limited us to Land East Hub.

\subsection{Organisation of the Study}

This study is divided into sections. Section one deals with the introductory background to the study, statement of the problem therein, objectives of the study, research questions, hypotheses, significance of the study, scope of the study and organisation of the study. Section two reviews conceptual literature (concept and theories of sustainable development required to do a critical analysis on the research problem and findings. Section three deals with the methodology bordering on the procedures adopted in order to attain the research objectives. These processes are contained in subsections relating to study area, research design, sources of data and data collection method, sample design/sampling procedures, population/sample size, research instrument and data analysis techniques/models. Section four deals with the presentation and analysis of data including hypotheses testing. The results obtained as well as their interpretations/discussions will be contained in this section. Section five takes a look at the summary, conclusions, and recommendations based on our findings and appendices will follow.

\section{Section Two: Conceptual Literature Review}

\subsection{The Concept and Theories of Sustainable Development}

The right to development implies the right to improvement and advancement of economic, social, cultural and political conditions. Improvement of global quality of life means the implementation of change that ensures every person has a life of dignity; or life in a society that respects and helps realize all human rights. These changes must include the eradication and alleviation of widespread conditions of poverty, unemployment, and inequitable social conditions. Sustainable development ensures the well-being of the human person by integrating social development, economic development, and environmental conservation and protection (Okowa, 2014). As the goal of sustainable development is to permanently improve the living conditions of human beings, social and economic developments must be carried out in a way that is environmentally and ecologically sound; ensuring the continual rejuvenation and availability of natural resources for future generations.

The UN Commission on Environment and Development in 1987 first launched the concept of "sustainable development". The Commission's milestone report (WCED, 1987, p. 1) "Our Common Future", defined sustainable development as "a development that meets the needs of the present without compromising the ability of future generations to meet their needs". Njiro (2002) opines that various interpretations of this definition have consequently emerged, differing along the disciplinary lines of ecology, economics, philosophy and others. While the debate still lingers on how to develop appropriate indicators for measuring the concept, there is a consensus that sustainability is the capacity for continuance into the future. The implication of this conclusion is that while ensuring the welfare of all, a path of economic and social development should not seek to maximize gains for this generation, if in so doing, it reduces the capacity of future generations to provide for their own wants and needs.

The UN Report also established that this requirement applies not only to environmental policies, but to 
Volume 8 Issue 3 March 2020

economic and social policies as well. The report was followed up at the Word Summit on Environment and Development, which took place at Rio de Janeiro in 1992 and adopted Agenda 21. Agenda 21 has since constituted a major reference in the formulation of policies pertaining to sustainable development (Ivbijaro, 2006 and National Sustainable Development Strategy, 2007). Among its basic tenets are the precautionary principle and the recognition that each government is responsible for creating conditions for sustainable development within its own borders, with the participation of its own population and international cooperation where needed. Sustainable development encompasses a number of basic political challenges: democratisation, equitable distribution of wealth, respect for human rights, combating corruption and sound resources management, to mention just a few, but essential elements. These issues cannot be handled within national borders alone. We therefore need to develop sound institutions at all levels, local, national, regional and global, to ensure that all these elements are reflected in future cooperation.

Sustainable development is a pattern of resource use that aims to meet human needs while preserving the environment so that these needs can be met not only in the present but in the indefinite future. Sustainable development ties together concern for the carrying of natural systems with the social challenges facing humanity. As early as the 1970s "sustainability" was employed to describe an economy "in equilibrium with basic ecological support system". Ecologists have pointed to the "limits of growth" and presented the alternative of a "steady state economy" in order to address environmental concerns. The field of sustainable development can be conceptually broken into three constituent parts: environmental sustainability, economic sustainability and socio-political sustainability.

The concept has included notions of weak sustainability, strong sustainability and deep ecology. Sustainable development does not focus solely on environmental issues. The United Nations 2005 World Summit Outcome Document refers to the "interdependent and mutually reinforcing pillars" of sustainable development as economic development, social development, and environmental protection (Okowa, 2004).

Indigenous people have argued, through various international for a such as the United Nations Permanent Forum on Indigenous Issues and the Convention on Biological Diversity, that there are four pillars of sustainable development, the fourth being cultural. The Universal Declaration on Cultural Diversity further elaborates the concept by stating that "... cultural diversity is as necessary for humankind as biodiversity is for nature", it becomes "one of the roots of development understood not simply in terms of economic growth, but also as a means to achieve a more satisfactory intellectual, emotional, moral and spiritual existence". In this vision, cultural diversity is the fourth policy area of sustainable development.

Economic Sustainability: Agenda 21 clearly identified information, integration, and participation as key building blocks to help countries achieve development that recognizes these interdependent pillars. It emphasizes that in sustainable development everyone is a user and provider of information. It stresses the need to change from oil sector-centred ways of doing business to new approaches that involve cross-sectional co-ordination and the integration of environmental and social concerns into all development processes. Furthermore, Agenda 21 emphasizes that broad public participation in decision making is a fundamental prerequisite for achieving sustainable development (WCED, 1987).

According to Hasna (2007), sustainability is a process which tells of a development of all aspects of human life affecting sustenance. It means resolving the conflict between the various competing goals, and involves the simultaneous pursuit of economic prosperity, environmental quality and social equity famously known as three dimension (triple bottom line) with the resultant vector being technology, hence it is a continually evolving process; the 'journey' (the process of achieving sustainability) is of course vitally important, but only as a means of getting to the destination (the desired future state). However, the 'destination' of sustainability is not a fixed place in the normal sense that we understand destination. Instead, it is a set of wishful characteristics of a future system.

Some research activities start from this definition to argue that the environment is a combination of nature and culture. The Network of Excellence "Sustainable Development in a Diverse World", sponsored by the European Union, integrates multidisciplinary capacities and interprets cultural diversity as a key element of a new strategy for sustainable development (Cohen \& Win, 2007). 
Volume 8 Issue 3 March 2020

Still other researchers view environmental and social challenges as opportunities for development action. This is particularly true of the concept of sustainable enterprise that frames these global needs as opportunities for private enterprise to provide innovative and entrepreneurial solutions.

It is on the above theoretical premise that SPDC saw the need for the development of host communities to be in tandem with best global practices of sustainable development goals; hence the company adopted a new development approach of GMoU which allows oil host communities drive their development for sustainability since 2006. How the GMoU process has fared in achieving sustainable development in the host communities given the enormity of efforts and funds deployed by SPDC since inception derives from the above conceptual and theoretical underpinnings.

\section{Section Three: Methodology}

\subsection{Introduction}

The focus of this section is to identify and enumerate various methods and procedures that were adopted in carrying out this study. This section was carried out under the following sub-headings: Area of Study, Research Design, Sources of Data and Data Collection Method, Field Work Methodology, Population/Sample and Sampling Techniques, Validity and Reliability of Research Instrument, Administration of Instrument, and Data Analysis Techniques.

\subsection{Area of Study}

A representative sample based on clusters is ideal for a study of this nature. Given the problems usually associated with covering all the 39 clusters in the three Hubs, the evaluation/survey study were carried out in three selected clusters of Land East Hub due largely to the paucity of funds and security challenges in extending to other two Hubs as initially planned. For effectiveness of coverage, sharper focus and minimising logistical problems the data collection was limited to 37 CTs in three clusters randomly selected: Etche $1-9$ CTs, Ikwerre - 15 CTs and Ukwa West- 15 CTs. This not only improved the accuracy and quality of data but was more representative of the underlying population and cost-effectiveness. Although this position raised the question of general is ability of the results to the rest of the 39 clusters in the other two Hubs, the gains thereof compensated for the perceived losses. There is no gainsaying that most of the clusters in Land East Hub have same identical epidemiological experiences in development financing policies, geographical contiguity and socio-economic problems as the other two Hubs - Central East and West.

The choice of the study area was predicated mainly on cost and security as it was considered that concentrating on three clusters within the Land East Hub, considered fairly safe and secure, provided a clearer focus, more effective supervision of the process and limited the cost and security challenges of expanding the study to the remaining clusters in the other two Hubs.

\subsection{Research Design}

Research design is a framework used as a guide for collecting and analysing data for a study (Baridan, 2001). How the study subjects will be brought into the scope of the research and how they will be employed within the research setting to yield the required data are all what research design entails (Ofo, 1994; White \& Clark, 1990). The nature of this study is both evaluation and survey. Therefore, this study adopted evaluation/survey design as the projects/programmes of the GMoU were evaluated to determine the extent to which they meet the objectives for which the model was adopted and established which enables us access quantitative data for answering our research questions and testing of our hypotheses. It is a mixed method/design that involves both quantitative and qualitative data acceptable in modern day research process. 
Volume 8 Issue 3 March 2020

\section{3 $\quad$ Sources of Data and Data Collection Method}

There are basically two sets of data in social research: primary and secondary (Ogolo, 1996; Nachmias \& Nachmias, 1981). Therefore, this study derived its data from both sources. However, empirical data for the study consisted mainly of primary data which derived from an evaluation/survey method with the instrument of questionnaire designed by the researcher, personal/oral interviews as well as focussed group discussions for the purpose of explanation of issues arising therein and for clarity of opinion of the respondents and getting facts from key stakeholders in the GMoU implementation process which included leaders of the clusters/CTs, SPDC's GMoU focal points and officials of the Mentoring and Facilitating NGOs in the three selected clusters of Land East Hub. In the design of a comprehensive questionnaire for this study (see Appendix B), adequate care was taken by the researcher to eliminate duplications considered inappropriate to the scope of this study.

The questionnaire composed of 82 items which were structured on a modified 4-point Likert rating scale described as suggestion in which respondents grade the responses to reflect their extent of agreements. The points were discrete points graduated in an ascending order of magnitude from ' 1 ' (lowest) '4' (highest) as indicated in the grading schedule of table 3.1 below:

Table 3.1: Grading Schedule

\begin{tabular}{|l|c|c|l|}
\hline Classification & Grade & Point & Exact limits \\
\hline Very High Extent & VHE & 4 & 3.50 and above \\
\hline High Extent & HE & 3 & $2.50-3.49$ \\
\hline Low Extent & LE & 2 & $1.50-2.49$ \\
\hline Very Low Extent & VLE & 1 & $0.00-1.49$ \\
\hline
\end{tabular}

\subsection{Population/Sample and Sampling Techniques}

The target population of the study is $120 \mathrm{CDB} / \mathrm{CT}$ members in the three selected clusters of Land East Hub. In a household survey framework, sample sizes usually vary depending on the purpose and size of the population. While it is often possible to work out the optimal sample size from the confidence interval of parameter estimates that a researcher is willing to accept, in practice more practical consideration tends to dominate the criteria for choice of a sample size. In Population surveys, sample to population ratio of 1:500 or even 1:2500 are admissible. However, there are standard techniques for determining the optimal size. According to Nwankwo (2006), the more conventional method (with different variants) is given by the Yamane (1967) formula that may be specified as:

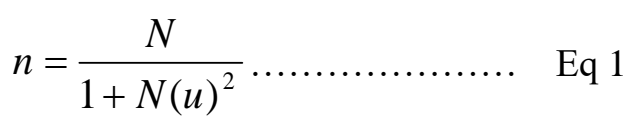

For $\mathrm{N}=$ population size and $\mathrm{u}=$ margin of error.

The Taro Yamane formula has an advantage of being simple to apply. It was therefore used in this case to calculate our optimal sample to population ratio. In standard statistical test of significance, it is usual to allow for five or one per cent margin of error. This survey allowed a 5 per cent margin of error in calculating the optimal sample size (i.e., $\mathrm{u}=$ 5\%). Noting that the population size $(\mathrm{N})$ in this case is 120 (Key CDB/CT members of 3 CDBs and $37 \mathrm{CTs}$ ) in the three selected clusters.

The projected population of the three selected clusters made up of key CDBs and CTs' membership is 120 .

Therefore, sample size is calculated as:

$N=120 /\left(1+120(0.05)^{2}\right)=92$

Thus, the number of subjects that was administered the instrument during the evaluation/survey study was 92 as stated above. However, it is often advisable to use sample size higher than the minimum estimate given by the formula 
Volume 8 Issue 3 March 2020

(Nwankwo, 2006) with a view to strengthening the reliability of the instruments. But due to funding constraints, we had to strictly keep to the sample size above. Furthermore, stratified random sampling technique was used to select the three clusters in Land East Hub out of the 39 clusters while basically considering certain variables like proximity, security, funding and performance over time as the basis for the selection of the three clusters as studying the entire 39 clusters was going to be cumbersome, herculean and unrealistic.

Then proportional stratified random sampling technique was used to compose the 92 subjects used for the study across the three clusters as each cluster had equal opportunity of being represented. Hypothetically, the proportional stratified random sampling for the study was:

Table 3.2: Proportional Stratified Random Sampling of the 112 Subjects

\begin{tabular}{|l|l|l|l|}
\hline Name of Cluster & Population & Proportion & Sample Size \\
\hline Etche 1 & 30 & 0.25 & $\mathbf{2 3}$ \\
\hline Ikwerre & 48 & 0.4 & $\mathbf{3 7}$ \\
\hline Ukwa West & 42 & 0.35 & $\mathbf{3 2}$ \\
\hline Grand Total & $\mathbf{1 2 0}$ & $\mathbf{1}$ & $\mathbf{9 2}$ \\
\hline
\end{tabular}

\subsection{Validity and Reliability of Instrument}

The validity of the instrument was based on face and content validity as a development expert with the support of colleagues in political science, sociology, Economics, and Education with a view to duly vetting the designed questionnaire. The instrument has eighty (82) questionnaire items bordering on the five research questions and five hypotheses set out in the study. While the test-retest reliability method was used, instrument was administered to ten respondents outside the sample study and size. The second test was administered after two weeks from the date the first test was administered to ensure high reliability coefficient. The result obtained was scored, coded and correlated using Pearson Product Moment Correlation (PPMC) for each section of the instrument and for the entire instrument. The reliability coefficient for all five sections of the instrument was 0.8 , an indication that our instrument was highly reliable.

\subsection{Administration of the Instrument}

Copies of the instrument (rating scale) were administered directly to the respondents by the researcher. One hundred and twenty(120) copies of the instrument were administered across the three selected clusters of Land East Hub above the sample size of 92 in line with proportional stratified random sampling adopted in this study.

\subsection{Data Analysis Techniques}

The scores on the responses from the CDBs/CTs were obtained from the questionnaire administered. After obtaining the scores, the lists were prepared and organised based on the independent variable (clusters of origin). The mean and standard deviation were computed based on the scale (Very High extent: 4, High extent: 3, low extent: 2, and very low extent:1). The criterion mean cut off of $2.5=(1+2+3+4) / 4$ was used to answer the research questions. Any item whose mean score is greater than or equal to 2.5 was accepted, while any item whose mean score was less than 2.5 was rejected. However, any item whose mean score lies between 3.50-above was regarded as very high extent, items with mean scores between 2.50-3.49 were regarded as High extent while items with mean scores between 1.50-2.49 were taken as low extent and items with mean scores between 0.00-1.49 were taken as very low extent.(see table 3.1 above). One-way Analysis of Variance (ANOVA) was used to test the five hypotheses at 0.05 level of significance. The Statistical Package for Social Sciences (SPSS) version 22.0 was used to run the data analysis to ascertain high degree of accuracy in the computations.

$$
M E A N=\frac{\sum f X}{\sum f}
$$




\section{Analysis of Variance}

Step 1: Correction term $(\mathrm{C})=\frac{\left(X_{1}+X_{2}+X_{3}\right)^{2}}{N_{1}+N_{2}+N_{3}}$

Step2: $S S_{\text {total }}=X_{1}^{2}+X_{2}^{2}+X_{3}^{2}+. .-C$

$$
S D=\sqrt{\frac{\sum f X^{2}}{\sum f}-\left(\frac{\sum f X}{\sum f}\right)^{2}}
$$

Step3: $S S_{\text {between.means }}=\left(X_{1}\right)^{2}+\left(X_{2}\right)^{2}+\ldots-C$

Step4: $S S_{\text {withingroup }}=S S_{\text {total }}-S S_{\text {means }}$

Step5: ANOVA table

\begin{tabular}{|l|c|c|c|c|c|}
\hline $\begin{array}{l}\text { Source of } \\
\text { variation }\end{array}$ & $\begin{array}{c}\text { Sum of } \\
\text { Squares }\end{array}$ & Df & $\begin{array}{c}\text { Mean } \\
\text { Square }\end{array}$ & F & p(Sig.) \\
\hline Between Groups & & & & & \\
\cline { 1 - 4 } Within Groups & & & & & \\
\hline Total & & & & & \\
\hline
\end{tabular}

$M S_{\text {within.group }}=\frac{S S_{\text {within.group }}}{D f_{\text {within.group }}}$

$F-$ value $=\frac{M S_{\text {between.group.means }}}{M S_{\text {within.group }}}$

(Amara \& Amaechi, 2005; Nwankwo, 2006 and

Ogolo, 2006).

Section Four: Data Presentation and Analysis

\subsection{Demographic Data}

Table 1: Distribution of the demographic variables

\begin{tabular}{llll} 
Demographics & Cluster & N & $\%$ \\
\hline Cluster & Cluster 1 Etche & 16 & 17.6 \\
& Cluster 2 Ikwerre & 45 & 49.5 \\
\multirow{4}{*}{ Gender } & Cluster 3 Ukwa-West & 30 & 33.0 \\
& Male & 54 & 59.3 \\
SOS & Female & 37 & 40.7 \\
& High & 25 & 27.5 \\
\multirow{3}{*}{ Education } & Low & 19 & 20.9 \\
& Moderate & 47 & 51.6 \\
& Primary & 7 & 7.7 \\
& Secondary & 28 & 30.8
\end{tabular}




\begin{tabular}{llll}
\multirow{4}{*}{ Age } & Tertiary & 56 & 61.5 \\
& Below 30 & 4 & 4.4 \\
& $30-34$ & 12 & 13.2 \\
Occupation & $35-40$ & 22 & 24.2 \\
& Above 40 & 53 & 58.2 \\
& Civil servant & 19 & 20.9 \\
& Company worker & 7 & 7.7 \\
& Trading & 15 & 16.5 \\
& Self-employed & 28 & 30.8 \\
& Not working & 22 & 24.2 \\
\hline
\end{tabular}

Table 1 shows the distribution of the demographic variables. It shows that most of the respondents, 45(49.50\%) were from Ikwerre. This was followed by 30(33.0\%) who were from Ukwa-West and the least, 16(17.6\%) were from Etche 1. More than half of the respondents, 54(59.3\%) of the respondents were males whereas 37(40.70\%) were females. About half, $51.6 \%$ of the respondents were from moderate socio-economic status, whereas $25(27.5 \%)$ were from high socio-economic status and 19(20.9\%) were from the low socio-economic status. Majority, 56(61.5\%) had tertiary education whereas $28(40.8 \%)$ had secondary education and the least were $7(7.7 \%)$ who had primary education. Most of the participants, 53(58.2\%) were above 40 years of age, whereas $22(24.2 \%)$ were in the age bracket of 35-40 years and the least were below 30 years, 4(4.4\%). Twenty eight representing 30.8\% of the participants were self-employed, whereas $22(24.2 \%)$ were not working and the least, 7(7.7\%) were company workers.

Table 2. Summary of mean rating on the GMoU implementation process fared in achieving sustainable development in three selected clusters since inception

\begin{tabular}{|c|c|c|c|c|c|c|c|c|c|}
\hline \multirow[t]{2}{*}{ SN } & \multirow[t]{2}{*}{ Item } & \multirow{2}{*}{$\begin{array}{l}\text { Etche } \\
\text { Cluster } \\
\text { n=16 } \\
\text { Mean } \\
\end{array}$} & \multirow[b]{2}{*}{ SD } & \multicolumn{2}{|c|}{$\begin{array}{l}\text { Ikwerre } \\
\text { Cluster } \\
\mathrm{n}=45\end{array}$} & \multicolumn{2}{|c|}{$\begin{array}{l}\text { Ukwa-west } \\
\text { Cluster } \\
\text { n=30 }\end{array}$} & \multicolumn{2}{|c|}{$\begin{array}{l}\text { Overall, } \\
\mathrm{n}=91\end{array}$} \\
\hline & & & & Mean & SD & Mean & SD & Mean & SD \\
\hline 1 & $\begin{array}{l}\text { To what extent have you been aware of the } \\
\text { existence of the GMoU model and } \\
\text { implementation process in your } \\
\text { Cluster/CT? }\end{array}$ & 3.5 & 0.82 & 3.6 & 0.58 & 3.4 & 0.86 & 3.52 & 0.72 \\
\hline 2 & $\begin{array}{l}\text { To what extent would you rate the cordial } \\
\text { relationship between SPDC and your } \\
\text { Cluster/CT? }\end{array}$ & 3.38 & 0.89 & 3.04 & 0.82 & 3.07 & 0.98 & 3.11 & 0.89 \\
\hline 3 & $\begin{array}{l}\text { To what extent would you acknowledge the } \\
\text { existence of GMoU projects/programmes in } \\
\text { your Cluster/CT? }\end{array}$ & 3.44 & 0.89 & 3.4 & 0.84 & 2.87 & 0.94 & 3.23 & 0.91 \\
\hline 4 & $\begin{array}{l}\text { To what extent would you say those } \\
\text { projects/programmes meet your immediate } \\
\text { Cluster/CT needs? }\end{array}$ & 3.38 & 0.89 & 3.18 & 0.72 & 2.97 & 0.85 & 3.14 & 0.8 \\
\hline 5 & $\begin{array}{l}\text { To what extent would you rate the impacts } \\
\text { of the GMoU infrastructural projects in } \\
\text { your Cluster/CT? }\end{array}$ & 3.50 & 0.89 & 3.2 & 0.76 & 2.9 & 0.96 & 3.15 & 0.87 \\
\hline 6 & $\begin{array}{l}\text { To what extent would you rate your } \\
\text { Cluster/CT's involvement of other } \\
\text { stakeholders in the planning, initiation, } \\
\text { implementation and monitoring of those } \\
\text { projects/programmes? }\end{array}$ & 2.75 & 1.00 & 2.93 & 0.99 & 2.63 & 1.07 & 2.80 & 1.01 \\
\hline
\end{tabular}


Volume 8 Issue 3 March 2020

7 To what extent are you aware that the GMoU model requires Sustainable

$\begin{array}{llllllll}3.19 & 0.83 & 3.47 & 0.73 & 3.10 & 1.16 & 3.30 & 0.91\end{array}$

Livelihoods Assessment (SLA) and Community Development Plans (CDP) as pre-condition for any project proposal and implementation?

8 To what extent has your Cluster/CT executed projects/programmes in line with Community Development Plans derived from Sustainable Livelihoods Assessment (SLA)?

9 To what extent are you aware that sustainability plans are pre-conditions for project conception and implementation in the GMoU process?

10 To what extent would you rate the inclusion of sustainability plans in project conception and implementation in the GMoU process by your $\mathrm{CDB} / \mathrm{CT}$ ?

11 To what extent would you rate the inclusion of human capital development into $\mathrm{CDB} / \mathrm{CT}$ projects/programme?

12 To what extent do you think human capital development projects/programmes of your $\mathrm{CDB} / \mathrm{CT}$ impact positively on the growth and development of your Cluster/CT?

13 To what extent would you rate the percentage of human capital development

\subsection{1}

3.31

0.95 3.00

0.83

2.30

$1.15 \quad 2.82$

1.03

3.38

$0.81 \quad 3.31$

$0.79 \quad 2.43$

$0.94 \quad 3.03$

0.94 in your GMoU implementation process?

14 To what extent do you consider environmental sustainability in the conception and implementation of $\mathrm{GMoU}$ projects/programmes in your Cluster/CT?

15 To what extent do you think the GMoU process has created wealth and reduced poverty in your Cluster/CT since inception?

16 To what extent has the GMoU process contributed to the creation of opportunities in your Cluster//CT since inception?

17 To what extent has the GMoU process developed your Cluster/CT to fit into job opportunities in Shell and other IOCs since inception?

18 To what extent would you agree that the GMoU process has addressed the actual sustainable development needs of your Cluster/CT?

19 To what extent would you agree that your $\mathrm{CDB} / \mathrm{CT}$ has contributed immensely to achieving values and social benefits to relevant stakeholders through the GMoU?

20 To what extent would you score the GMoU in terms of optimal performance?

Grand mean

\subsection{5}

2.69

$\begin{array}{lllllll}1.01 & 2.20 & 0.94 & 2.03 & 0.93 & 2.23 & 0.97 \\ & & & & & & \\ 1.12 & 1.89 & 1.03 & 2.00 & 1.08 & 1.96 & 1.05\end{array}$

2.06

$1.00 \quad 2.69$

$0.82 \quad 2.20$

$0.85 \quad 2.59$

0.91

2.63

$1.09 \quad 2.51$

$0.94 \quad 2.50$

$0.97 \quad 2.53$

0.97

2.75

$0.91 \quad 2.27$

$1.05 \quad 2.25$

1.00

$1.12 \quad 1.89$

$1.03 \quad 2.00$

$1.08 \quad 1.96$

1.05

3.06

$0.93 \quad 2.82$

$0.81 \quad 2.30$

$0.95 \quad 2.69$

0.92

2.88

$\begin{array}{llll}1.02 & 3.02 & 0.66 & 2.47\end{array}$

$0.73 \quad 2.81$

0.79

2.44

$1.15 \quad 2.36$

$1.15 \quad 2.27$

$1.11 \quad 2.34$

1.13

3.07

$\begin{array}{ll}0.71 & 2.93\end{array}$

$0.46 \quad 2.63$

$0.48 \quad 2.86$
$1.00 \quad 2.07$ 
Volume 8 Issue 3 March 2020

The result from Table 2 shows that the mean rating on how GMoU implementation process has fared in achieving sustainable development since inception in the three selected clusters - Etche 1, Ikwerre and Ukwa West with mean ratings of $3.07 \pm 0.71 ; 2.93 \pm 0.46 ; 2.63 \pm 0.48$ respectively. Generally the overall mean rating of the GMoU implementation process has fared in achieving sustainable development in three selected clusters since inception hence revealing a mean rating of $2.86 \pm 0.54$. Specifically, considering the overall mean rating, the respondents indicated strongly to the question on the extent they have been aware of the existence of the GMoU model and implementation process in their Cluster/CT $(\mathrm{M}=3.52, \mathrm{SD}=0.72)$, this was followed by the extent they have been aware of the existence of the GMoU model and implementation process in their Cluster/CT with a mean score of $3.30, \mathrm{SD}=0.91$ and following the criterion mean rating of 2.50 the least mean rating as agreed by the respondents was the extent they considered environmental sustainability in the conception and implementation of GMoU projects/programmes in your Cluster/CT(2.53, $\mathrm{SD}=0.97)$.

Table 3: Summary of mean rating of the applicability and functionality of the principles of transparency and accountability in the implementation of the GMoU process in three selected clusters over the years

\begin{tabular}{|c|c|c|c|c|c|c|c|c|c|}
\hline \multirow[t]{2}{*}{ SN } & \multirow[t]{2}{*}{ Item } & \multicolumn{2}{|c|}{$\begin{array}{l}\text { Etche } \\
\text { Cluster } \\
\mathbf{n}=16\end{array}$} & \multicolumn{2}{|c|}{$\begin{array}{l}\text { Ikwerre } \\
\text { Cluster }\end{array}$} & \multicolumn{2}{|c|}{$\begin{array}{l}\text { Ukwa-west } \\
\text { Cluster }\end{array}$} & \multicolumn{2}{|c|}{$\begin{array}{l}\text { Over All, } \\
\text { n=91 }\end{array}$} \\
\hline & & Mean & SD & Mean & SD & Mean & SD & Mean & SD \\
\hline 21 & $\begin{array}{l}\text { To what extent are you conversant with the } \\
\text { amount of funds allocated to your } \\
\text { Cluster/CT for her yearly GMoU projects/ } \\
\text { programmes? }\end{array}$ & 3.13 & 0.89 & 3.29 & 0.84 & 2.7 & 1.18 & 3.07 & 1 \\
\hline 22 & $\begin{array}{l}\text { To what extent would you rate your } \\
\text { adequate knowledge of how the Cluster/CT } \\
\text { funds are being expended? }\end{array}$ & 2.63 & 1.09 & 2.98 & 0.97 & 2.57 & 1.01 & 2.78 & 1.01 \\
\hline 23 & $\begin{array}{l}\text { To what extent would you rate your } \\
\text { adequate knowledge of the existence of } \\
\text { ethical business principles and values in the } \\
\text { implementation of the GMoU } \\
\text { projects/programmes in your Cluster/CT? }\end{array}$ & 2.69 & 1.14 & 2.62 & 0.83 & 2.1 & 0.92 & 2.46 & 0.95 \\
\hline 24 & $\begin{array}{l}\text { To what extent would you rate your } \\
\text { CDB/CT's strict adherence to ethical } \\
\text { business principles and values in the } \\
\text { implementation of the GMoU } \\
\text { projects/programmes? }\end{array}$ & 2.81 & 0.91 & 2.89 & 0.75 & 2.63 & 0.89 & 2.79 & 0.82 \\
\hline 25 & $\begin{array}{l}\text { To what extent would you agree that your } \\
\mathrm{CDB} / \mathrm{CT} \text { has managed the GMoU process } \\
\text { in a transparent and accountable manner } \\
\text { since inception? }\end{array}$ & 2.81 & 1.17 & 3.27 & 0.78 & 2.6 & 0.89 & 2.97 & 0.94 \\
\hline 26 & $\begin{array}{l}\text { To what extent would you rate the } \\
\text { provision of accurate, timely and } \\
\text { unambiguous information on the activities } \\
\text { of your CDB/CT to critical stakeholders? }\end{array}$ & 2.5 & 1.03 & 2.89 & 0.8 & 2.57 & 1.04 & 2.71 & 0.93 \\
\hline 27 & $\begin{array}{l}\text { To what extent would you agree that your } \\
\mathrm{CDB} / \mathrm{CT} \text { regularly declares assets, sources } \\
\text { and uses of funds accruable to the } \\
\mathrm{CDB} / \mathrm{CT} \text { ? }\end{array}$ & 2.69 & 1.01 & 3 & 0.88 & 2.4 & 1 & 2.75 & 0.97 \\
\hline 28 & $\begin{array}{l}\text { To what extent would you agree that the } \\
\text { CDB/CT regularly publishes and } \\
\text { disseminates narrative of activities and } \\
\text { financial reports of the CDB/CT to relevant } \\
\text { stakeholders? }\end{array}$ & 2.5 & 1.21 & 2.58 & 0.97 & 2.43 & 1.1 & 2.52 & 1.05 \\
\hline
\end{tabular}


Volume 8 Issue 3 March 2020

29 To what extent does your CDB/CT hold regular dialogue/townhall sessions with key stakeholders of the GMoU process to review projects and other activities?

30 To what extent would you agree that $\mathrm{CDB} / \mathrm{CT}$ members declare their interests and avoid conflicts of interest in managing the GMoU process?

31 To what extent would you agree that the accounts and activities of the $\mathrm{CDB} / \mathrm{CT}$ are regularly audited internally and externally to ensure transparency and accountability of the GMoU process?

32 To what extent do you agree that your $\mathrm{CDB} / \mathrm{CT}$ complies substantially with the modes/specifications of contract awards, payments and monitoring in the GMoU process?

33 To what extent would you agree that the Technical Committee of your CDB substantially lives up to its responsibilities in contract award and monitoring?

34 To what extent would you agree that your $\mathrm{CDB} / \mathrm{CT}$ maintains open offices with paid 2.81

$\begin{array}{ll}1.05 & 3.27\end{array}$

0.84

2.97

$\begin{array}{lll}1.1 & 3.09 & 0.97\end{array}$

staff and up-to-date state-of-the-art facilities/assets given the enormity of administrative funds allocated to implement the GMoU process?

35 To what extent would you agree that members of host communities/clusters are in the knowledge of the activities of your $\mathrm{CDB} / \mathrm{CT}$, hence make observations and contributions towards their improvement of the process?

$\begin{array}{llllllll}2.81 & 0.98 & 3.36 & 0.71 & 3.1 & 0.88 & 3.18 & 0.84\end{array}$

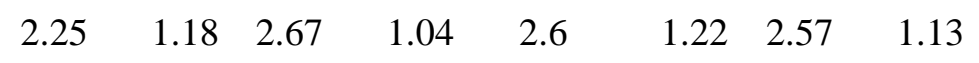

$\begin{array}{llllllll}2.94 & 1.06 & 3.49 & 0.73 & 2.83 & 1.05 & 3.18 & 0.95\end{array}$

$\begin{array}{lllllllll}3 & 1.15 & 3.58 & 0.58 & 3.07 & 0.94 & 3.31 & 0.87 \\ 2.63 & 0.96 & 3.09 & 0.82 & 3.17 & 0.95 & 3.03 & 0.9\end{array}$

Grand mean

$\begin{array}{llllllll}2.70 & 0.72 & 3.10 & 0.46 & 2.70 & 0.56 & 2.90 & 0.58\end{array}$

The result from Table 3 ascertained the applicability and functionality of the principles of transparency and accountability in the implementation of the GMoU over the years process in the three selected clusters- Etche 1, Ikwerre and Ukwa West with a mean ratings of $2.70 \pm 0.72 ; 3.10, \pm 0.46$ and $2.70 \pm 0.56$ respectively. Generally the overall mean rating of Table 3 ascertained the applicability and functionality of the principles of transparency and accountability in the implementation of the GMoU process in the three selected clusters over the years which resulted to a mean rating of $2.90 \pm 0.58$, which also revealed that the respondents agreed to a great extent that the technical committee of your CDB substantially lives up to its responsibilities in contract award and monitoring ( $\mathrm{M}=3.31$, $\mathrm{SD}=0.87$ ). This was followed closely by the respondents agreeing that the $\mathrm{CDB} / \mathrm{CT}$ complies substantially with the modes/specifications of contract awards payment and monitoring in the GMoU process with a mean score of $3.18 \pm 0.95$ and following a criterion mean rating of 2.50 the least as agreed was on the extent would they agree that the $\mathrm{CDB} / \mathrm{CT}$ regularly publishes and disseminates narrative of activities and financial reports of the $\mathrm{CDB} / \mathrm{CT}$ to relevant stakeholders $(\mathrm{M}=2.52, \mathrm{SD}=1.05)$ 
Table 4: Summary of the mean ratings on ascertaining the extent to which the CDBs/CTs have implemented the principle of inclusiveness in the GMoU process in three selected clusters over time

\begin{tabular}{|c|c|c|c|c|c|c|c|c|c|}
\hline \multirow[t]{2}{*}{ SN } & \multirow[t]{2}{*}{ Item } & \multicolumn{2}{|c|}{$\begin{array}{l}\text { Etche } \\
\text { Cluster } \\
\mathbf{n}=16\end{array}$} & \multicolumn{2}{|c|}{$\begin{array}{l}\text { Ikwerre } \\
\text { Cluster } \\
\mathrm{n}=45\end{array}$} & \multicolumn{2}{|c|}{$\begin{array}{l}\text { Ukwa-west } \\
\text { Cluster } \\
\text { n=30 }\end{array}$} & \multicolumn{2}{|c|}{$\begin{array}{l}\text { overall, } \\
\mathrm{n}=91\end{array}$} \\
\hline & & Mean & SD & Mean & SD & Mean & SD & Mean & SD \\
\hline 36 & $\begin{array}{l}\text { To what extent do you understand the } \\
\text { principle of 'inclusiveness' as enshrined in } \\
\text { the GMoU model? }\end{array}$ & 2.75 & 0.93 & 3.13 & 0.99 & 3.03 & 0.85 & 3.03 & 0.94 \\
\hline 37 & $\begin{array}{l}\text { To what extent do you agree that the } \\
\text { GMoU process engendered the delivery of } \\
\text { equitable benefits to all segments of the } \\
\text { society, especially the vulnerable groups } \\
\text { including women and youths? }\end{array}$ & 3,00 & 0.97 & 3.36 & 0.86 & 3.10 & 0.99 & 3.21 & 0.93 \\
\hline 38 & $\begin{array}{l}\text { To what extent do you agree that the } \\
\text { GMoU implementation process has } \\
\text { involved women, youths and poorest in } \\
\text { decision-making, planning and project } \\
\text { implementation activities? }\end{array}$ & 2.94 & & 3.27 & 0.84 & 3.37 & 0.81 & 3.24 & 0.85 \\
\hline 39 & $\begin{array}{l}\text { To what extent would you agree that the } \\
\text { GMoU implementation process has } \\
\text { involved existing community /cluster } \\
\text { interest groups through all steps of the } \\
\text { participatory planning cycle as a means of } \\
\text { encouraging ownership of the process? }\end{array}$ & & & 3.11 & 0.65 & 3.03 & 0.89 & 3.00 & 0.82 \\
\hline 40 & $\begin{array}{l}\text { To what extent do you agree that there is } \\
\text { appropriate representation of all segments } \\
\text { of the Cluster/CT in the governing } \\
\text { structures of the GMoU? }\end{array}$ & 2.75 & 0.93 & 3.31 & 0.76 & 3.10 & 0.96 & 3.14 & 0.88 \\
\hline 41 & $\begin{array}{l}\text { To what extent do you agree that your } \\
\text { CDB/CT works in synergy with all } \\
\text { existing, recognised and respected } \\
\text { traditional authority structures to mobilise, } \\
\text { inform and invite the different } \\
\text { segments/stakeholders in the Cluster/CT } \\
\text { development activities? }\end{array}$ & 3.13 & 0.96 & 3.18 & 0.65 & 2.90 & 1.18 & 3.08 & 0.91 \\
\hline 42 & $\begin{array}{l}\text { To what extent would you agree that the } \\
\text { GMoU implementation process has } \\
\text { enhanced intra/inter community } \\
\text { relationships developed through clustering } \\
\text { process? }\end{array}$ & 3.19 & 1.05 & 2.76 & 0.98 & 2.87 & 1.07 & 2.87 & 1.02 \\
\hline 43 & $\begin{array}{l}\text { To what extent would you agree that the } \\
\text { GMoU implementation process is meant } \\
\text { to build bridges across all divides in the } \\
\text { Cluster/CT with a view to giving all a } \\
\text { sense of belonging? }\end{array}$ & 2.69 & 1.08 & 2.93 & 0.81 & 2.80 & 1.03 & 2.85 & 0.93 \\
\hline 44 & $\begin{array}{l}\text { To what extent would you agree that the } \\
\text { current agitation for balkanisation of the } \\
\text { CDBs/CTs is borne purely out of scuttling } \\
\text { the 'inclusiveness' the process is meant to }\end{array}$ & 2.69 & 1.01 & 2.67 & 1.13 & 2.37 & 1.07 & 2.57 & 1.09 \\
\hline
\end{tabular}


Volume 8 Issue 3 March 2020

achieve instead of administrative gains as claimed?

45 To what extent would you agree that relevant stakeholders in the GMoU $\begin{array}{llllllll}2.44 & 1.09 & 1.87 & 1.06 & 2.37 & 1.07 & 2.13 & 1.09\end{array}$ process are all 'carried along' by your $\mathrm{CDB} / \mathrm{CT}$ leadership?

Grand mean

2.82

$0.68 \quad 3.0$

$0.49 \quad 2.89$

$0.50 \quad 2.91$

$\mathbf{0 . 5 3}$

The result from Table 4 reveals the affirmation of the respondents on the extent to which the CDBs/CTs have implemented the principle of inclusiveness in the GMoU process in the three selected clusters-Etche 1, Ikwerre and Ukwa West with mean ratings of $2.82 \pm 0.68 ; 3.00 \pm 0.49 ; 2.89 \pm 0.50$, respectively. It further reveals with an overall mean rating that the respondents affirmed greatly the extent to which the CDBs/CTs have implemented the principle of inclusiveness in the GMoU process in the three selected clusters over time revealing a mean rating of 2.91 \pm 0.53 . More so, the respondents agreed strongly that the GMoU implementation process involved women, youths and the poorest in decision-making, planning and project implementation activities which resulted to $3.24 \pm 0.85$. More so, but of the least rating as agreed by the respondents was the extent they agreed that the current agitation for balkanisation of the $\mathrm{CDBs} / \mathrm{CTs}$ is borne purely out of scuttling the 'inclusiveness' the process is meant to achieve instead of administrative gains as claimed( $\mathrm{M}=2.57, \mathrm{SD}=1.09)$.

Table 5: Summary of mean rating on the roles of the CDBs/CTs in grievance handling in the GMoU implementation process in three selected clusters since inception.

\begin{tabular}{|c|c|c|c|c|c|c|c|c|c|}
\hline \multirow{3}{*}{ SN } & \multirow{3}{*}{ Item } & \multirow{2}{*}{\multicolumn{2}{|c|}{$\begin{array}{l}\text { Etche } \\
\text { Cluster } \\
\text { n=16 }\end{array}$}} & \multicolumn{2}{|c|}{$\begin{array}{l}\text { Ikwerre } \\
\text { Cluster }\end{array}$} & \multicolumn{2}{|c|}{$\begin{array}{l}\text { Ukwa-west } \\
\text { Cluster }\end{array}$} & \multirow{2}{*}{\multicolumn{2}{|c|}{$\begin{array}{l}\text { Overall, } \\
\mathrm{n}=91\end{array}$}} \\
\hline & & & & $n=45$ & & $n=30$ & & & \\
\hline & & Mean & SD & Mean & SD & Mean & SD & Mean & SD \\
\hline 46 & $\begin{array}{l}\text { To what extent are you in the knowledge of } \\
\text { grievance handling procedures in the GMoU } \\
\text { process? }\end{array}$ & 2.63 & 1.15 & 3 & 1 & 2.3 & 1.09 & 2.70 & 1.09 \\
\hline 47 & $\begin{array}{l}\text { To what extent have you observed any } \\
\text { aggrieved persons in your Cluster/CT report } \\
\text { their grievances first to their CTs from } \\
\text { where such emanated? }\end{array}$ & 2.31 & 0.95 & 2.67 & 0.93 & 2.93 & 1.05 & 2.69 & 0.99 \\
\hline 48 & $\begin{array}{l}\text { To what extent have such grievances so } \\
\text { reported to your CT been transmitted to the } \\
\text { SPDC representatives (CRO/CIC) of that } \\
\text { area within } 48 \text { hours by the CT Chairman } \\
\text { and Secretary? }\end{array}$ & 2.44 & 1.21 & 2.87 & 1.01 & 2.67 & 1.09 & 2.73 & 1.08 \\
\hline 49 & $\begin{array}{l}\text { To what extent have such grievances been } \\
\text { responded to by the SPDC representative } \\
\text { (CRO/CIC) with a view to resolving them } \\
\text { within } 72 \text { hours? }\end{array}$ & 2.13 & 1.02 & 2.49 & 1.01 & 2.5 & 1.11 & 2.43 & 1.05 \\
\hline 50 & To what extent have such grievances & 2.19 & 0.91 & 2.33 & 0.88 & 2.07 & 0.94 & 2.22 & 0.9 \\
\hline
\end{tabular}
requiring consultation with SPDC been escalated by the CRO to the responsible $\mathrm{CRC} / \mathrm{CIC}$ with a view to responding to them within 48 hours of receiving them form the CT?

51 To what extent would you agree that your CT usually meets within two weeks of receiving grievances to resolve them?

52 To what extent would you agree that where

$\begin{array}{llllllll}2.38 & 1.09 & 3.04 & 0.82 & 2.57 & 1.07 & 2.77 & 0.99 \\ & & & & & & & \\ 2.19 & 0.98 & 3.02 & 0.97 & 2.37 & 1.1 & 2.66 & 1.07\end{array}$


the grievances had not been resolved by the $\mathrm{CT}$, the grievances had been escalated to the CDB conflict management sub-committee to resolve within 2 weeks?

53 To what extent would you agree that where the CDB conflict management subcommittee is unable to resolve such grievances, that they had been escalated to the State/Local Government to resolve?

54 To what extent would you agree that any aggrieved persons had only gone to court after failing to secure redress from the State/Local Government?

55 To what extent would you agree that most aggrieved persons in your CT had only gone to court after exhausting all the dispute resolution processes laid down in the GMoU model?

56 To what extent have aggrieved persons disrupted the operations of the company through violent activities and stoppage of work in breach of the GMoU agreement?

57 To what extent have aggrieved parties reported criminal acts/cases of public disorder or conducts likely to cause breach of the peace to relevant security agencies for appropriate actions?

58 To what extent do you agree that lack of adherence to grievance handling procedures has negatively affected the smooth implementation of the GMoU process and has often led to clamour for splitting of the $\mathrm{CDBs} / \mathrm{CTs}$ ?

59 To what extent would you agree that adherence to grievance handling procedures by the aggrieved persons in your Cluster/CT would enhance the implementation of the GMoU process?

60 To what extent would you agree that your $\mathrm{CDB} / \mathrm{CT}$ and other relevant State/Local Government authorities have not activated and complied with the grievance handling procedures over the years?

61 To what extent would you agree that relative understanding of grievance handling procedures by the appropriate authorities as enshrined in the GMoU model would limit the plethora of litigations in court by the constituents of various Clusters/CTs?

Grand Total $\begin{array}{llllllll}1.94 & 0.85 & 1.82 & 1.01 & 2.07 & 1.01 & 1.92 & 0.98\end{array}$

$\begin{array}{llllllll}2.25 & 1.24 & 1.89 & 1.01 & 1.9 & 1.06 & 1.96 & 1.06\end{array}$

$\begin{array}{llllllll}2.19 & 1.11 & 2.24 & 1.19 & 1.93 & 1.14 & 2.13 & 1.16\end{array}$

$\begin{array}{llllllll}1.19 & 0.54 & 1.67 & 0.98 & 1.63 & 1 & 1.57 & 0.93\end{array}$

$\begin{array}{llllllll}1.69 & 0.95 & 2.18 & 1.03 & 1.83 & 1.02 & 1.98 & 1.02\end{array}$

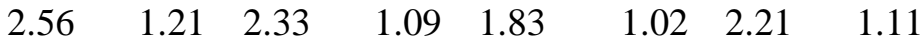

$\begin{array}{llllllll}2.75 & 1.18 & 3.36 & 0.77 & 2.3 & 1.06 & 2.90 & 1.05\end{array}$

$\begin{array}{llllllll}2.06 & 1.12 & 1.87 & 0.92 & 2.1 & 1.16 & 1.98 & 1.03\end{array}$

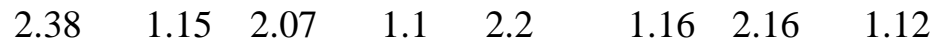

The result from Table 5 reveals the mean ratings of the roles of the CDBs/CTs in grievance handling in the GMoU implementation process since inception in the three selected clusters- Etche 1, Ikwerre and UkwaWest with a 
Volume 8 Issue 3 March 2020

mean ratings of $2.20, \mathrm{SD}=0.64 ; 2.43, \mathrm{SD}=0.42 ; 2.20, \mathrm{SD}=0.52$, respectively. It further shows the overall mean rating on the roles of the CDBs/CTs in grievance handling in the GMoU implementation process in three selected clusters since inception was 2.31 ; $\mathrm{SD}=0.51$. Specifically, the respondents however agreed that the adherence to grievance handling procedures by the aggrieved persons in the Clusters/CT would enhance the implementation of the GMoU process with a mean of $2.90 \pm 1.05$, this was followed by the item indicating the extent would they agree that their CT usually meets within two weeks of receiving grievances to resolve them $(\mathrm{M}=2.77, \mathrm{SD}=0.99)$. Following a criterion mean score of 2.50, the least mean rating was on the extent they agree that where the grievances had not been resolved by the CT, the grievances had been escalated to the CDB conflict management sub-committee to resolve within 2 weeks $(\mathrm{M}=2.66, \mathrm{SD}=1.07)$.

Table 6: Summary of mean rating on the roles of successive Mentoring and Facilitating NGOs in the GMoU process in three selected clusters over the years

\begin{tabular}{|c|c|c|c|c|c|c|c|c|c|}
\hline \multirow[t]{2}{*}{ SN } & \multirow[t]{2}{*}{ Item } & \multicolumn{2}{|c|}{$\begin{array}{l}\text { Etche } \\
\text { Cluster } \\
\mathrm{n}=16\end{array}$} & \multicolumn{2}{|c|}{$\begin{array}{l}\text { Ikwerre } \\
\text { Cluster } \\
\text { n=45 }\end{array}$} & \multicolumn{2}{|c|}{$\begin{array}{l}\text { Ukwa-west } \\
\text { Cluster } \\
\text { n=30 }\end{array}$} & \multicolumn{2}{|c|}{$\begin{array}{l}\text { Overall } \\
\mathrm{n}=91\end{array}$} \\
\hline & & Mean & SD & Mean & SD & Mean & SD & Mean & SD \\
\hline 62 & $\begin{array}{l}\text { To what extent would you agree that } \\
\text { successive Mentoring and Facilitating NGOs } \\
\text { have helped to add substantial values to the } \\
\text { GMoU process in the following areas: }\end{array}$ & 2.81 & 1.22 & 3.4 & 0.75 & 2.93 & 1.14 & 3.14 & $\overline{1.01}$ \\
\hline 63 & Project proposal and delivery & & & 3.53 & 0.73 & 3.1 & 1.09 & 3.35 & 0.91 \\
\hline 64 & $\begin{array}{l}\text { Documentation of value of work done by } \\
\text { GMoU contractors/vendors (VOWD) }\end{array}$ & & & 2.98 & 0.94 & 3.1 & 1.03 & 3.04 & 0.99 \\
\hline 65 & $\begin{array}{l}\text { Stakeholder management and reputation } \\
\text { management (Support of SPDC position) }\end{array}$ & & 1.1 & 2.96 & 0.9 & 3.03 & 0.85 & 2.99 & 0.91 \\
\hline 66 & $\begin{array}{l}\text { Provision of Baseline Reports and Sustainable } \\
\text { Livelihood Assessment Reports within } 30 \\
\text { days afterward }\end{array}$ & 2.69 & 1.14 & 2.56 & 1.14 & 2.7 & 1.06 & 2.63 & 1.10 \\
\hline 67 & $\begin{array}{l}\text { Achievement of zero budget overrun on } \\
\text { annual budget/cluster }-95 \%\end{array}$ & 2.75 & 1.06 & 2.56 & 1.06 & 2.9 & 0.88 & 2.70 & 1.01 \\
\hline 68 & $\begin{array}{l}\text { Monthly reports - projects/programmes status } \\
\text { including financials and VOWD }-2^{\text {nd }} \text { day of } \\
\text { every successive month }\end{array}$ & 2.44 & 1.15 & 2.40 & 0.91 & 2.7 & 1.02 & 2.51 & 0.99 \\
\hline 69 & $\begin{array}{l}90 \% \text { of community issues managed and } \\
\text { closed out with } 5 \text { days of occurrence }\end{array}$ & 2.81 & 1.17 & 3.11 & 1.03 & 2.83 & 1.12 & 2.97 & 1.08 \\
\hline 70 & 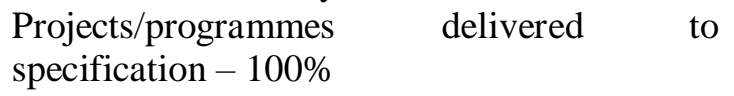 & 2.81 & 1.05 & 2.96 & 0.88 & 2.57 & 1.22 & 2.80 & 1.04 \\
\hline 71 & $\begin{array}{l}\text { Zero failure of FTO/Community Trust and } \\
\text { Support }\end{array}$ & 2.50 & 1.15 & 2.73 & 0.91 & 2.77 & 0.9 & 2.70 & 0.95 \\
\hline 72 & $\begin{array}{l}100 \% \text { of issues which may impact reputation, } \\
\text { assets or disrupt worksite/operations shared } \\
\text { with Shell - weekly report }\end{array}$ & 2.50 & 1.21 & 2.09 & 1.04 & 2.90 & 1.06 & 2.43 & 1.13 \\
\hline 73 & $\begin{array}{l}\text { To what extent have successive Mentoring } \\
\text { and Facilitating NGOs helped to mentor the } \\
\text { CDBs/CTs in capacity building in the } \\
\text { following areas: }\end{array}$ & 2.19 & 1.17 & 1.8 & 0.92 & 2.63 & 1.13 & 2.14 & 1.09 \\
\hline 74 & $\begin{array}{l}\mathrm{CDB} / \mathrm{CT} \text { partnership with other development } \\
\text { stakeholders in their development activities to } \\
\text { maximise resources and establish mutually } \\
\text { beneficial interactions }\end{array}$ & 2.38 & 1.26 & 2.31 & 1.10 & 2.83 & 1.02 & 2.49 & 1.12 \\
\hline 75 & $\begin{array}{l}\text { Attraction of funds from other development } \\
\text { partners to complement the GMoU funds } \\
\text { from SPDC for Cluster/CT development }\end{array}$ & 2.94 & 0.93 & 2.69 & 1.04 & 2.9 & 1.03 & 2.80 & 1.01 \\
\hline 76 & Enhancement of intra/inter community & 2.94 & 1.06 & 2.71 & 1.16 & 2.67 & 1.06 & 2.74 & 1.10 \\
\hline
\end{tabular}


relationships for inclusiveness with a view to reducing the agitation for split of the $\mathrm{CDB} / \mathrm{CT}$ and peaceful co-existence of all segments of the Cluster/CT

77 Development and implementation of appropriate HSE policy and procedure for activities to promote environmental sustainability

78 Promotion of ownership, sustainability and the power of communities to actualise or drive their development process

79 Maintenance of functional offices, office equipment and assets for the CDBs/CTs and adequate supervision in line with standards

80 Maintenance/training of functional personnel in their own offices and those of the CDBs for the smooth running of the Clusters/CTs

81 Training of members of the CDBs/CTs in book/record keeping and all GMOU processes

82 Strict monitoring of all GMoU activities to $\begin{array}{lllllll}3.06 & 1.12 & 2.71 & 1.01 & 2.93 & 1.08 & 2.85\end{array}$

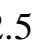

\subsection{6}

ensure accountability, transparency, inclusiveness, sustainability and timely resolution of all conflicts in the Clusters/CTs

Grand Mean

The result from Table 6 reveals the mean ratings of theroles of successive mentoring and facilitating NGOs in the GMoU process clusters over the years in three selected- Etche 1,Ikwerre and Ukwa West - $2.75 \pm 0.74 ; 2.75 \pm 0.61$; $2.84 \pm 0.72$ respectively. It further shows the overall mean rating of theroles of successive mentoring and facilitating NGOs in the GMoU process in three selected clusters over the years to be $2.77 ; \mathrm{SD}=0.67$. Moreover, the respondents affirmed the Project proposal and delivery a mean rating of 3.35, SD $=0.91$. This was followed by the responses on the extent they would agree that successive mentoring and facilitating NGOs have helped to add substantial values to the GMoU process in the following areas $(\mathrm{M}=3.14, \mathrm{SD}=1.01)$. Based on the criterion mean score of 2.50, the least mean rating on the affirmative the extent they would agree that monthly reports - projects/programmes status including financials and VOWD $-2^{\text {nd }}$ day of every successive month are executed $(\mathrm{M}=2.51, \mathrm{SD}=0.99)$.

\subsection{Test of Hypotheses}

$\mathbf{H}_{\mathbf{0 1}}$ : There is no significant difference in the perception of the CDBs/CTs that the GMoU has achieved sustainable development in three selected clusters.

$\mu_{1}=\mu_{2}=\mu_{3}$ Or $\mu_{1}-\mu_{2}-\mu_{3}=0$

Table 7: Summary of One Way ANOVA design on the difference in the perception of the CDBs/CTs that the GMoU has achieved sustainable development in the three selected clusters

\begin{tabular}{lccccc}
\hline $\begin{array}{l}\text { Source of } \\
\text { variation }\end{array}$ & $\begin{array}{c}\text { Sum of } \\
\text { Squa es }\end{array}$ & Df & $\begin{array}{c}\text { Mean } \\
\text { Square }\end{array}$ & F & Sig. \\
\hline Between Groups & 2.473 & 2 & 1.237 & 4.569 & .013 \\
Within Groups & & & & & \\
& 23.814 & 88 & .271 & & \\
Total & 26.287 & 90 & & & \\
\hline
\end{tabular}


Volume 8 Issue 3 March 2020

The result from Table 7 shows the summary of One-Way ANOVA design on the difference in the perception of the $\mathrm{CDBs} / \mathrm{CT}$ s that the GMoU has achieved sustainable development in the three selected clusters. It shows that there is significant difference in the perception of the CDBs/CTs that the GMoU had achieved sustainable development in the selected three clusters. (F2, 88=4.569, p<.05). Hence, the null hypothesis was rejected at .05 level of significance.

Table 7b: Summary of Scheffe's post hoc test of multiple comparison on the difference in the perception of the CDBs/CTs that the GMoU has achieved sustainable development in the three selected clusters

\begin{tabular}{|c|c|c|c|c|c|c|}
\hline \multirow[t]{2}{*}{ (I) cluster } & \multirow[t]{2}{*}{ (J) cluster } & \multirow{2}{*}{$\begin{array}{c}\text { Mean } \\
\text { Difference } \\
\text { (I-J) }\end{array}$} & \multirow[t]{2}{*}{$\begin{array}{l}\text { Std. } \\
\text { Error }\end{array}$} & \multirow[t]{2}{*}{ Sig. } & \multicolumn{2}{|c|}{$\begin{array}{l}\text { 95\% Confidence } \\
\text { Interval }\end{array}$} \\
\hline & & & & & $\begin{array}{l}\text { Lower } \\
\text { Bound }\end{array}$ & $\begin{array}{l}\text { Upper } \\
\text { Bound }\end{array}$ \\
\hline & cluster 2 Ikwerre & 13986 & .15142 & .654 & -.2372 & .5169 \\
\hline cluster 1 etche & $\begin{array}{l}\text { Cluster } 3 \text { Ukwa } \\
\text { west }\end{array}$ & $.43708^{*}$ & .16104 & .029 & .0361 & .8381 \\
\hline & cluster 1 etche & -.13986 & .15142 & .654 & -.5169 & .2372 \\
\hline cluster 2 Ikwerre & $\begin{array}{l}\text { Cluster } 3 \text { Ukwa } \\
\text { west }\end{array}$ & .29722 & .12261 & .058 & -.0081 & .6025 \\
\hline Cluster 3 Ukwa & cluster 1 etche & $-.43708^{*}$ & .16104 & .029 & -.8381 & -.0361 \\
\hline west & cluster 2 Ikwerre & -.29722 & .12261 & .058 & -.6025 & .0081 \\
\hline
\end{tabular}

*. The mean difference is significant at the 0.05 level.

Table $7 \mathrm{~b}$ shows the summary of Scheffe's post hoc test of multiple comparisons on the difference in the perception of the CDBs/CTs that the GMoU has achieved sustainable development in the three selected clusters. It further shows that the mean difference between cluster-1 Etche and cluster -3 Ukwa west was significant $(\mathrm{MD}=.43708, \mathrm{p}<.05)$ in favour of cluster-1 Etche.

$\mathbf{H O}_{2}$ : There is no significant difference in the perception of the CDBs/CTs thatthe

GMoU process has been transparently and accountably managed in line with

extant principles of the model in the three selected clusters.

$$
\mu_{1}=\mu_{2}=\mu_{3} \quad \text { or } \quad \mu_{1}-\mu_{2}-\mu_{3}=0
$$

Table 8: Summary of One Way ANOVA design on the difference in the perception of the CDBs/CTs that the GMoU has been transparently and accountably managed in line with extant principles of the model in the three selected clusters.

\begin{tabular}{lccccc}
\hline Source of variation & $\begin{array}{c}\text { Sum of } \\
\text { Squares }\end{array}$ & Df & $\begin{array}{c}\text { Mean } \\
\text { Square }\end{array}$ & F & Sig. \\
\hline Between Groups & 3.790 & 2 & 1.895 & 6.376 & .003 \\
Within Groups & 26.151 & 88 & .297 & & \\
Total & 29.941 & 90 & & & \\
\hline
\end{tabular}

The result from Table 8 shows the summary of One Way ANOVA design on the difference in the perception of the $\mathrm{CDBs} / \mathrm{CT}$ s that the GMoU process has been transparently and accountably managed in line with extant principles of the model in the three selected clusters. It shows a significant difference in the perception of the CDBs/CTs that the GMoU had been transparently and accountably managed in line with extant principles of the model in the selected three clusters. $(\mathrm{F} 2,88=6.376, \mathrm{p}<.05)$. Hence, the null hypothesis was rejected. 
Volume 8 Issue 3 March 2020

Table 8: Summary of Scheffe's post hoc test of multiple comparison on the difference in the perception of the CDBs/CTs that the GMoU has been transparently and accountably managed in line with extant principles of the model in the three selected clusters

\begin{tabular}{|c|c|c|c|c|c|c|}
\hline \multirow[t]{2}{*}{ (I) cluster } & \multirow[t]{2}{*}{$(\mathrm{J})$ cluster } & \multirow{2}{*}{$\begin{array}{c}\text { Mean } \\
\text { Difference } \\
(\mathbf{I}-\mathbf{J}) \\
\end{array}$} & \multirow{2}{*}{$\begin{array}{l}\text { Std. } \\
\text { Error }\end{array}$} & \multirow[t]{2}{*}{ Sig. } & \multicolumn{2}{|c|}{ 95\% Confidence Interval } \\
\hline & & & & & Lower Bound & Upper Bound \\
\hline \multirow[b]{2}{*}{ cluster 1 etche } & cluster 2 Ikwerre & $-.40398^{*}$ & .15867 & .044 & -.7991 & -.0089 \\
\hline & $\begin{array}{l}\text { Cluster } 3 \text { Ukwa } \\
\text { west }\end{array}$ & .00639 & .16876 & .999 & -.4138 & .4266 \\
\hline \multirow[b]{2}{*}{ cluster 2 Ikwerre } & cluster 1 etche & $.40398^{*}$ & .15867 & .044 & .0089 & .7991 \\
\hline & $\begin{array}{l}\text { Cluster } 3 \text { Ukwa } \\
\text { west }\end{array}$ & $.41037^{*}$ & .12849 & .008 & .0904 & .7303 \\
\hline Cluster 3 Ukwa & cluster 1 etche & -.00639 & .16876 & .999 & -.4266 & .4138 \\
\hline west & cluster 2 Ikwerre & $-.41037^{*}$ & .12849 & .008 & -.7303 & -.0904 \\
\hline
\end{tabular}

Table $8 \mathrm{~b}$ shows the summary of Scheffe's post hoc test of multiple comparisons on the difference in the perception of the CDBs/CTs that the GMoU has been transparently and accountably managed in line with extant principles of the model in the three selected clusters. It further shows that the mean difference between cluster-1 Etche1 and cluster-2 Ikwerre was significant $(\mathrm{MD}=.40398, \mathrm{p}<.05)$ in favour of cluster-Etche1.

$\mathrm{H0}_{3}$ : The CDBs/CTs do not differ in their perception that the principle of inclusiveness has been substantially implemented in the GMoU process in line with extant principles of the model in three selected clusters.

$$
\mu_{1}=\mu_{2}=\mu_{3} \quad \text { or } \quad \mu_{1}-\mu_{2}-\mu_{3}=0
$$

Table 9 Summary of One Way ANOVA design on the difference in the perception that the principle of inclusiveness has been substantially implemented in the GMoU process in line with extant principles of the model in three selected clusters.

\begin{tabular}{lccccc}
\hline Source of variation & $\begin{array}{c}\text { Sum of } \\
\text { Squares }\end{array}$ & Df & $\begin{array}{c}\text { Mean } \\
\text { Square }\end{array}$ & F & Sig. \\
\hline Between Groups & .244 & 2 & .122 & .433 & .650 \\
Within Groups & 24.793 & 88 & .282 & & \\
Total & 25.037 & 90 & & &
\end{tabular}

The result from Table 9 shows the summary of One Way ANOVA design on the difference in the perception that the principle of inclusiveness has been substantially implemented in the GMoU process in line with extant principles of the model in the three selected clusters. It shows no significant difference in the perception of the CDBs/CTs that the principle of inclusiveness has been substantially implemented in the GMoU process in line with extant principles of the model in the selected three clusters. (F2, $88=.433$, p>.05). The null hypothesis was retained.

H0$_{4}$ : The CDBs/CTs do not differ in their perception that the grievance handling procedures as enshrined in the GMoU model have been substantially activated in resolving the myriad of conflicts arising from the implementation process in three selected clusters. 


$$
\mu_{1}=\mu_{2}=\mu_{3} \text { Or } \mu_{1}-\mu_{2}-\mu_{3}=0
$$

Table 10: Summary of One Way ANOVA design on the difference in the grievance handling procedures as enshrined in the GMoU model has been substantially activated in resolving the myriad of conflicts arising from the implementation process in three selected clusters.

\begin{tabular}{lccccc} 
Source of variation & $\begin{array}{c}\text { Sum of } \\
\text { Squares }\end{array}$ & Df & $\begin{array}{c}\text { Mean } \\
\text { Square }\end{array}$ & F & Sig. \\
\hline Between Groups & 1.169 & 2 & .585 & 2.327 & .104 \\
Within Groups & 22.108 & 88 & .251 & & \\
Total & 23.277 & 90 & & & \\
\hline
\end{tabular}

The result from Table 10 shows the summary of One Way ANOVA design on the difference in the grievance handling procedures as enshrined in the GMoU model has been substantially activated in resolving the myriad of conflicts arising from the implementation process in three selected clusters.It shows no significant difference in the grievance handling procedures as enshrined in the GMoU model being substantially activated in resolving the myriad of conflicts arising from the implementation process in three selected clusters. (F2, 88=2.327, p>.05). The null hypothesis was retained at .05 level of significance.

H05: $_{5}$ The CDBs/CTs do not significantly differ in their perception that successive Mentoring and Facilitating NGOs have substantially added values to the

GMoU process in three selected clusters.

$$
\mu_{1}=\mu_{2}=\mu_{3} \quad \text { or } \quad \mu_{1}-\mu_{2}-\mu_{3} \bumpeq 0
$$

Table 11: Summary of One Way ANOVA design on the difference of the CDBs/CTs in their perception that successive Mentoring and Facilitating NGOs have substantially added values to the GMoU process in three selected clusters.

\begin{tabular}{lllllc} 
Source of variation & \multicolumn{1}{c}{$\begin{array}{c}\text { Sum of } \\
\text { Squares }\end{array}$} & Df & $\begin{array}{c}\text { Mean } \\
\text { Square }\end{array}$ & F & Sig. \\
\hline Between Groups & .155 & 2 & .078 & .173 & .841 \\
Within Groups & 39.478 & 88 & .449 & & \\
Total & 39.633 & 90 & & & \\
\hline
\end{tabular}

The result from Table 11 shows the summary of One Way ANOVA design on the difference of the CDBs/CTs in their perception that successive Mentoring and Facilitating NGOs have substantially added values to the GMoU process in three selected clusters.It shows no significant difference of the CDBs/CTs in their perception that successive Mentoring and Facilitating NGOs have substantially added values to the GMoU process in three selected clusters. (F, $=.173, \mathrm{p}>.05)$. The null hypothesis was retained.

\subsection{Discussion of findings}

The state of the GMoU implementation process in achieving sustainable development

The result from Table 2 showed that the GMoU implementation process in achieving sustainable development since inception was most favourable to Etche1 cluster, as reflected on their mean rating of $3.07 \pm 0.71$, followed by Ikwerre who had mean rating of $2.93 \pm 0.46$ and the least was Ukwa West with mean rating of $2.63 \pm 0.48$ respectively. The overall mean rating of $2.86 \pm 0.54$ indicated that all three clustered fared well in the GMoU implementation process in achieving sustainable development since inception based on a criterion mean of 2.50 on the 4-point scale. 
Volume 8 Issue 3 March 2020

When put to statistical test, the result of Analysis of Variance on Table 7 showed that there is significant difference in the perception of the CDBs/CTs that the GMoU had achieved sustainable development in the selected three clusters. $(\mathrm{F} 2,88=4.569, \mathrm{p}<.05)$. Hence, the null hypothesis was rejected at .05 level of significance.

\section{The applicability and functionality of the principles of transparency and accountability in the implementation of the GMoU process over the years}

The result from Table 3 ascertained the applicability and functionality of the principles of transparency and accountability in the implementation of the GMoU over the years process was most favourable to Ikwerre cluster as shown in their mean rating of $3.10 \pm 0.46$, whereas Etche1 and UkwaWest had mean ratings of $2.70 \pm 0.72$ and $2.70 \pm 0.56$ respectively. The overall mean rating of $2.90 \pm 0.58$ which was above the criterion mean rating of 2.50 showed that the applicability and functionality of the principles of transparency and accountability in the implementation of the GMoU process over the years was above average. When put to statistical test, the result of Analysis of Variance on Table 8 showed that there is significant difference in the perception of the CDBs/CTs that the GMoU process has been transparently and accountably managed in line with extant principles of the model in the three selected clusters. $(F 2,88=6.376$, p<.05). Hence, the null hypothesis two was rejected at .05 level of significance.

\section{Ascertaining the extent to which the CDBs/CTs have implemented the principle of inclusiveness in the GMoU process}

The result from Table 4 revealed that the extent to which the CDBs/CTs have implemented the principle of inclusiveness in the GMoU process was most favourable to lkwerre who had mean rating of $3.00 \pm 0.49$, followed by Ukwa West with mean rating of $2.89 \pm 0.50$ and Etche1 cluster who had a mean rating of $2.82 \pm 0.68$ respectively. The overall mean rating of $2.91 \pm 0.53$ affirmed greatly the extent to which the CDBs/CTs have implemented the principle of inclusiveness in the GMoU process in the three selected clusters over time. When put to statistical test, the result of Analysis of Variance on Table 9 showed that there is no significant difference in the perception of the CDBs/CTs that the GMoU had been transparently and accountably managed in line with extant principles of the model in the selected three clusters $(F 2,88=.433, \mathrm{p}>.05)$. The null hypothesis three was retained at .05 level of significance.

\section{The roles of the CDBs/CTs in grievance handling in the GMoU implementation process}

The result from Table 5 reveals the roles of the CDBs/CTs in grievance handling in the GMoU implementation process since inception was most favourable to the Ikwerre cluster, who rated the variable with a mean score of $2.43 \pm 0.42$ whereas Etche 1 and Ukwa West had mean ratings of $2.20 \pm 0.64$ and $2.20 \pm 0.52$ respectively. The overall mean rating on the roles of the CDBs/CTs in grievance handling in the GMoU implementation process in three selected clusters since inception was $2.31 \pm 0.51$. When put to statistical test, the result of Analysis of Variance on Table 10 showed that there is no significant difference in the grievance handling procedures as enshrined in the GMoU model being substantially activated in resolving the myriad of conflicts arising from the implementation process in three selected clusters. $(\mathrm{F}, 88=2.327, \mathrm{p}>.05)$. The null hypothesis four was retained at .05 alpha level.

\section{The roles of successive Mentoring and Facilitating NGOs in the GMoU process}

The result from Table 6 revealed that the mean ratings Etche 1, Ikwerre and UkwaWest on the roles of successive mentoring and facilitating NGOs in the GMoU process clusters over the years were $2.75 \pm 0.74,2.75 \pm 0.61$ and $2.84 \pm 0.72$ respectively. The overall mean rating of the roles of successive mentoring and facilitating NGOs in the GMoU process over the years was $2.77 \pm 0.67$. When put to statistical test, the result of Analysis of Variance on Table 11 showed that there is no significant difference of the CDBs/CTs in their perception that successive Mentoring and Facilitating NGOs have substantially added values to the GMoU process in three selected clusters. $(\mathrm{F},=.173, \mathrm{p}>.05)$. The null hypothesis five was retained at .05 level of significance. 
Volume 8 Issue 3 March 2020

\subsection{Conclusion and Recommendations}

This study essentially focussed on appraising SPDC's Global Memorandum of Understanding (GMoU) model and Implementation Process in three selected clusters of Land East Hub. Although SPDC was not the first IOC in Nigeria to adopt and implement this new global community development model, yet its GMoU model and implementation process have remained one of the most successful in the history of sustainable community development processes in the country. Four hypotheses tested positive except one, an indication that the GMoU model and implementation process have substantially complied with the principles and objectives of the Operating Principles and Procedure Guidelines (OPPG). Out of the five hypotheses tested, grievance handling in the GMoU process failed the litmus test. What this means is that the grievance handling procedures as enshrined in the GMoU process, since inception, have not been adequately activated by the CTs and CDBs including the GMoU focal points in the three selected clusters of Ikwerre, Etche 1 and Ukwa West. Apart from this, the GMoU model has been able achieve substantially the principles and objectives for which it was set up by the Shell Petroleum Development Company of Nigeria Limited. Although it can be said from the findings of the research that the model has achieved sustainable development in the three selected clusters of Ikwerre, Etche 1, and Ukwa West, there exist some gaps between the GMoU model and the implementation process, owing largely to the failure of the focal points alongside the CTs and CDBs to live up to the dictates of the GMoU agreements.

The study, therefore, concludes that in spite of the achievements of the GMoU model in the selected three clusters, the need to overhaul the implementation process has become imperative to sustain the community-driven development process. The study, however, recommends a return to early years of GMoU implementation process at inception where all the GMoU focal points religiously lived up to the dictates of the OPPG with a view to closing the widening gaps and addressing the age-long development needs of the oil host communities on a sustainable basis.

\section{References}

Amara, T.C. \& Amaechi, A.E. (2005). Manual of Research Methodology and Thesis Writing. Aba: Ker expert Books.

Asika, N. (2006). Research Methodology in Behavioural Science. Ikeja: Longman Nig. Plc.

Baridan, D. (2001). Research Methodology in Management Science. Port Harcourt: Belt Publishers.

Cohen, B. \& Winn, M.I. (2007). Market imperfections, opportunity and sustainable entrepreneurship. Journal of Business Venturing, 22(1), 29-49.

Hasna, A.M. (2007). Dimensions of sustainability. Journal of Engineering for Sustainable Development: Energy, Environment, and Health, 2(1), 47-57.

Ivbijaro, M.F.A. (2006). Sustainable development in Nigeria. In M.F.A. Ivbijaro; F. Akintola \& R.V. Okechukwu (Eds.),Sustainable Environmental Management in Nigeria(pp. 23-41). Ibadan: College Press \& Publishers Ltd,

Nachmias, D. \&Nachmias, C. (1981). Research Methods in the Social Sciences (2nd ed.). New York: St. Martin's Press.

National Sustainable Development Strategy (2007, September). Second Draft, Belgrade. Retrieved January 3, 2009, 
from http://www.un.or/esa/agenda21/natlinfo/coutr/serbia/nsds. serbia.pdf.

Njiro, E. (2002). Sustainable Development: An Oxymoron. Durban: Agenda Feminist Media Company.

Nwankwo, O.C. (2006). Guide to Writing Research Writing. Port Harcourt: Pam Unique Publishers.

Ofo, J.E. (1994). Research Methods and Statistics in Education and Social Sciences. Lagos: Joja Press Ltd.

Ogolo, M.B. (1996). Students' Guide to writing Project Proposals and Research. Port Harcourt: City Creeks Publishers.

Okowa, W. (2004). Economic Planning in Nigeria. Port Harcourt: Belk Publisher.

Operating Principles and Procedure Guidelines (OPPG). (2017, May). Standards and best practices for implementing the Global Memorandum of Understanding (GMoU) in SPDC Host Communities (Signed copy).

Shell in Nigeria Briefing Notes. (2019, April). Nigeria: Shell International

SPDC (n.d). Retrieved September 30, 2019, from httpps//shell.com.ng/sustainability/communities/gmou.html

Study Team Report on Proposed Community Interface Model for SPDC. (2006, December). Global Memorandum of Understanding. SCD Strategic Implementation Model Review, 2005.

WCED. (1987). Report of the World Commission on Environment and Development. General Assembly Resolution 42/187, 11 December 1987. Retrieved April 12, 2009, from http://www.un.or/documents/ga/res/42/ares42187.htm.

White, L.G. \& Clark, R.P. (1990). Political Analysis Technique and Practice. California: Brooks/Cole Publishing Company.

Yamene, T. (1967). Statistics: An Introductory Analysis(2 ${ }^{\text {nd }}$ ed.). New York: Harper and Row. 